ROCZNIKI KULTUROZNAWCZE

Tom XI, numer $2 \quad-\quad 2020$

DOI: http://dx.doi.org/10.18290/rkult20112-4

MACIEJ B. STĘPIEŃ

\title{
THE KEY TO ENLIGHTENMENT: JOHN TOLAND'S “CLIDOPHORUS” AND HIS GRAND THEORY OF THE ESOTERIC AND EXOTERIC DOCTRINES
}

\section{INITIAL REMARKS: THE "NOUN OF CONFUSION"}

It has been over a decade since the print of the Dictionary of Gnosis and Western Esotericism (DGWE), ${ }^{1}$ which is now a standard reference work for the academic study of esotericism. Outstanding contributions making up this hefty work not only did not eclipse, but even more emphasized the fact that "gnosis" and "esotericism" are a peculiar, closely related couple of terms. The first one is ancient, the other is thoroughly modern. One is deeply rooted in religious belief and philosophical stances, the other has been invented, (or, more precisely, reinvented) only recently, and then projected on many historically evident cultural phenomena directly connected with broadly conceived Gnostic religiosity. Even the sheer length of the articles in DGWE, dedicated to gnosis and esotericism respectively, reflect this contrast. ${ }^{2}$

This overlapping of esotericism and gnosis is an unintentional side-effect, as the term „esotericism” (or „western esotericism”) has been cast on nearly everything that made up the pool of the so-called "rejected knowledge" in Western culture. ${ }^{3}$ As a result, the entire, multifaceted cultural fallout of an-

\footnotetext{
MACiej B. STĘPIEŃ, PhD — historian of ideas, translator of scientific publications; address for correspondence-e-mail: maciejbstepien@gmail.com. ORCID: https://orcid.org/0000-0003-30622890.

${ }^{1}$ Dictionary of Gnosis and Western Esotericism, ed. Wouter J. Hanegraaff and Roelof van den Broek (Leyden: Brill, 2006). Henceforth abbreviation: DGWE.

${ }^{2}$ Roelof van den Broek, "Gnosticism," in DGWE, 403-32; Wouter J. HanegraAfF, "Esotericism," in DGWE, 336-40.

${ }^{3}$ Cf. Wouter J. Hanegraaff, "The Birth of Esotericism from the Spirit of Protestantism," Aries 10 (2010), 2: 197-216; IDEM, Esotericism and the Academy: Rejected Knowledge in Western Culture (Cambridge: Cambridge University Press, 2012). Reviewed by Marco PASI, "The
} 
cient Gnosticism and Gnostic religiosity made the bulk of what is now called "esotericism", while not exactly fitting definitions given to it. What now has been gathered under the label of "esotericism" are alternative and dissident religious and philosophical currents, rejected by mainstream religion and Academia in a long and perfectly traceable process spanning roughly 150 years, from mid- $16^{\text {th }}$ century until the beginning of the Enlightenment era: astrology, divination, ceremonial, popular, and daemonic magic, alchemy, Paracelsianism, Christian theosophy, Christian kabbalah, rosicrucianism, their continuations in freemasonry (Masonic High Degrees), 'Western' and 'Eastern' brands of occultism, anthroposophy and their many derivatives and reformulations.

This projection of the term-encompassing, as a result, many currents of human thought, which have never referred to themselves as "esoteric"-is the main reason for the present intellectual upheaval and lively debate concerning esotericism. What remains certain is that esotericism can be safely defined only as an "abstract noun with unstable meanings that shift both within and between socio-cultural formations", 4 and that "despite much theoretical work geared towards criticizing and deconstructing the term itself it is still deployed in conflicting ways in different research programs." ${ }^{5}$

Those are but a few of the numerous meta-subjective issues at hand, belonging to the ongoing, wider methodological discussion concerning esotericism as a field of academic study. ${ }^{6}$ But there is even more: in the contemporary studies on esotericism, the pre-history of the term also presents itself as a not-so-clearly painted picture. Recent discoveries by Monika Neugebauer-Wölk have shown Esoterismus and Exoterismus to be a fully grown pair of notions picked up in 1776 by a German philosopher, Johann Georg Hamman (1730-1788). This thinker seems to be the first one who moved from previously known adjectives „esoteric” and „exoteric” towards nomina propria. $^{7}$ It was a considerable change, although only a lexical one.

problems of rejected knowledge: thoughts on Wouter Hanegraaff's Esotericism and the Academy," Religion 43 (2013), issue 2: 201-12.

4 Egil Asprem, "Reverse-engineering 'esotericism': how to prepare a complex cultural concept for the cognitive science of religion," Religion 46 (2016), issue 2: 165.

${ }^{5}$ Ibid., 159.

${ }^{6}$ Cf. Maciej B. StęPIeń, “ ‘Wczesny Faivre’ czy ‘pełny Hanegraaf’? Dylematy metodologiczne ezoteryki zachodniej”, in Tożsamość w ezoterycznych nurtach kultury, ed. Agata Świerzowska and Izabela Trzcińska (Kraków: Wydawnictwo LIBRON — Filip Lohner, 2016), 129-44.

${ }^{7}$ Cf. Asprem, 'Reverse-engineering 'esotericism,' 166. He refers to the article authored by Monika Neugebauer-WöLk, "Historische Esoterikforschung, oder: Der lange Weg der Esoterik zur Moderne," in Aufklärung und Esoterik: Wege in die Moderne, ed. Monika Neugebauer-Wölk et al. (Berlin, Boston: De Gruyter, 2013), 41-43, 51-58. 
What stood behind this transition from adjectives to nouns, however, and what likely has caused the language to be thus improved, was a concept which had already been there in the times of Hamman: a concept emphasizing the (alleged) immense cultural weight and the utmost importance of this "esoteric thing" that seemed to be right there, hidden and waiting to be discovered, in the literary, philosophical, and religious heritage of the West.

In 1770s., already several decades had past during which a vision had been circulating among Western enlightened elites - a vision big and bold enough to provoke Georg Hamman's enquiring mind to give this "esoteric thing," seemingly omnipresent in culture, a proper name. The author of this vision was John Toland (1670-1722), and this paper will discuss his specific approach to the history of human thought, his original theory of the exoteric and esoteric doctrines, and that theory's immediate consequences. I will argue that the scale and boldness of John Toland's theory constitutes a legitimate ground for conclusions regarding the likely path of transition from the use of adjectives (esoteric/exoteric) to the use of nouns (esotericism/exotericism) during the Enlightenment era. In this theory we encounter a very likely candidate for the efficient cause of all this. Toland's theory gives also rise to some thoughts regarding the specificity of the Enlightenment era in general, especially with regard to what has been labeled as "illuminism." 8

\section{ANCIENT DECEIVERS}

Certainly, it is an exciting time for scholars studying western esotericism, as even today we are able to discover forgotten historical sources that shed a new light on the subject. And one of them, dating back half a century before Georg Hamman's work, is a true gem: "Clidophorus" by John Toland (1670-1722), dated 1720. ${ }^{9}$ The Author of this unique historical source did not use nomina propria. He only used adjectives: 'esoteric' and 'exoteric', but, then again, he worked them into the frame of a comprehensive theory aimed at the explaining the entire history of humankind in terms of a grand quest for philosophical and religious truth. In his treatise, Toland argued that the division of exoteric and esoteric doctrines was crucial for the development of the entire human civilization and culture, in every epoch and place.

\footnotetext{
${ }^{8}$ Cf. Christine Bergé, "Illuminism”, in DGWE, 601-6.

9 Already discussed briefly in Maciej B. STĘPIEŃ, Okultyzm: studium ezoteryki zachodniej (Lublin: Academicon, 2015), 98-101.
} 
John Toland prepared what he thought was the 'key to the truth'. Hence the title of his treatise: "Clidophorus" - the Bearer of the Key.

"Clidophorus" is not easy to find by its title, as it was never published as a standalone work. It was a part of Toland's tetralogy under the title of Tetradymus, which translates as "Four Scares" or "Four-fold Fear." Each of the four parts of this work referred to a different subject, and each was meant to constitute a warning for the reader regarding dangers awaiting every philosopher who dares to seek the truth. "Clidophorus" was part two of this book. ${ }^{10}$ But this was not the only circumstance that hid "Clidophorus" from the sight of scholars of today. Tetradymus was originally written in Latin, two years before the Author's death. It was then kept in secret; its copies were privately printed and distributed only among John Toland's closest and most trusted friends. It was not until 1751 that its English version appeared publicly in print, dated, however, according to its first edition: 1720. Nobody reprinted it ever again, and only recently, due to the $21^{\text {st }}$-century grand projects of digitalization of our libraries, it became accessible worldwide. In 1751, however, Tetradymus was immediately spotted and included in the pool of general knowledge of the mid- $18^{\text {th }}$ century, with "Clidophorus" ending up as the only source-material for the lexicographical entry on the meaning of the adjective 'esoteric', published in a supplement to the famous Dictionnaire de Trevoux (1752).

Toland introduced himself in "Clidophorus" as a historian who studied the past to elucidate history of esoteric and exoteric philosophy. ${ }^{11}$ It is worthwhile to note that he took up the oldest, simplest and straightforward meaning of the two adjectives - the one originated in a $2^{\text {nd }}$-century satire written by Lucian of Samosata: what was esoteric was „secret, inner and hidden” while exoteric meant „public, outer and openly stated”. ${ }^{12}$ But this division between secret and public teachings was not, according to Toland, by any means a joke but, quite frankly, the universal method of cultivating philosophy. Toland wrote:

${ }^{10}$ John Toland, "Clidophorus; or of the Exoteric and Esoteric Philosophy, that is, of the External and Internal Doctrine of the Antients," in IDEM, Tetradymus (London: J. Brotherton et al., 1720), 63-100.

${ }^{11}$ Ibid., 82.

${ }^{12}$ It was all Lucian's joke about Aristotelian philosophers: when you buy one, you actually buy two in one, because one is on the outside, and another one hides inside (one is 'exoterikos' and the other is 'esoterikos'). See Lucian of Samosata, "The Sale of the Philosophical Sects," in IDEM, Lucian of Samosata, vol. 1, trans. William Tooke (London: Longman, Hurst, Rees, Orme, and Brown, 1820), 215-36. Later English translations changed the title to Philosophies for Sale, Creeds for Sale, and Sale of Creeds, 
This distinction of Exoterical and Esoterical doctrines was, as it were, the Catholic establishment of all nations; which shows that Universality is no infallible mark of TRUTH, unless it be maintain'd that there is more wisdom than folly, more honesty than wickedness, more knowledge than ignorance in the world. ${ }^{13}$

Therefore the truth might be known only to a few, and Toland argued in support of the thesis that ancient authors had deceived the public, openly teaching only superficial and misleading subjects, while indicating at the same time the existence of a hidden side of philosophy - the one regarding plain truth. Moreover, he hinted at the fact that he himself was familiar with the content of this true, but hidden, 'esoteric' philosophy. In other words: he himself possessed that secret. He knew the truth. And he kept it secret just like his predecessors.

\section{PERSONAL PRACTICE AND A HERMENEUTIC KEY}

In his own life, Toland consistently put this approach into practice, always separating his openly declared views from those which remained private, and if put to paper, were written in Latin, and distributed among his friends only. ${ }^{14}$ In the final words of "Clidophorus" he reminded his readers that

from the whole tenor of this Dissertation it may be easily conceiv'd; how hard it is to come at TRUTH your self, and how dangerous a thing to publish it to others. ${ }^{15}$

Thus, it is safe to assume that it was first his own practice of separating privately shared knowledge from public statements (due to fear of persecution), from which his theory, contained in "Clidophorus", originated. In his own words:

\footnotetext{
${ }^{13}$ Toland, "Clidophorus," 81.

${ }^{14}$ Today, we also know what this "hidden" and "dangerous" philosophical doctrine actually was in Toland's mind. It was the concept of panentheism, developed by Baruch Spinoza (16321677). This concept was indicated many times by Toland as the truth veiled in superstition, falshoods, institutional compulsion, enforcement and persecutions. More on Toland and his views in Margaret C. $\mathrm{J}_{\mathrm{ACOB}}$, The Radical Enlightenment: Pantheists, Freemasons and Republicans, $2^{\text {nd }}$ rev. ed. (New Orleans: Cornerstone Book Publishers, 2006); Daniel C. Fouke, Philosophy and Theology in a Burlesque Mode: John Toland and the Way of Paradox (New York: Prometheus Books, 2008).

${ }^{15}$ Toland, "Clidophorus," 100.
} 
The Philosophers therfore, and other well-wishers to mankind in most nations, were constrain'd by this holy tyranny to make use of 'a two-fold doctrine; the one Popular, accomodated to the Prejudices of the vulgar, and to the receiv'd Customs or Religions: the other Philosophical, conformable to the nature of things, and consequently to TRUTH; which, with doors fast shut and under all other precautions, they communicated onely to friends of known probity, prudence, and capacity'. These they generally call'd the Exoteric and Esoteric, or the External and Internal Doctrines. That such a distinction they us'd, and that they practis'd accordingly, I am now going to show (being the subject of this Dissertation) by a select Collection I made of passages to this purpose, out of abundance of others, scatter'd up and down the antient writers. ${ }^{16}$

To substantiate his theory, Toland quoted only a few philosophers of GrecoRoman antiquity. Despite this, he emphasized that all known cultures of the world, especially Oriental ones, knew and practiced this division of knowledge. To persuade his readers, Toland dropped a few clauses on this, distributing them between the third and fourth chapter of his work. In the ending of chapter III we can spot a remark on Egyptians, from whom Pythagoras

learn[ed] the genuin sens of the mystical doctrine: which ... they discover'd to none, except when intreated with the utmost importunity, and soften'd by complaisance and assiduity. ${ }^{17}$

Right after this, in the opening of Chapter IV, we encounter the whole catalogue of cultures supposedly mimicking this Egyptian custom:

This double manner of teaching was also in use among other oriental nations, especially the Ethiopians and Babylonians, the antient and modern Bramins, the Syrians, Persians, and the rest, principally instructed by ZOROASTER. ... The Druids of the Gauls and Britons wou'd by no means deliver their mysteries or secret doctrines, to any except the initiated: that I may say nothing of the Hetruscans, and other Occidental nations, no more than of the present Chinese, Siamese and Indians. ${ }^{18}$

Thus, early in the $18^{\text {th }}$ century, Toland's treatise bound both terms, 'esoteric' and 'exoteric,' with a grand theory that challenged nearly everything that was known to be the philosophical heritage of Western civilization. On top of that, "Clidophorus" presented these terms as a new and general, hermeneutic key, with the help of which this heritage should be studied. The division between intentionally hidden truth and openly taught deceit was,

\footnotetext{
${ }^{16}$ Ibid., $65 \mathrm{f}$.

${ }^{17}$ Ibid., 72.

${ }^{18}$ Ibid.
} 
according to Toland, not some detail found in obscure and marginal treatises of this or that ancient author. No. It was exactly the opposite: the division of doctrines into 'esoteric' and 'exoteric' ones was an intentionally laid foundation of all ancient philosophical knowledge, worldwide. And for this reason every rational, methodological approach to studying the philosophical content produced in ancient times - in every language and culture - must take into account this division. Such was the ultimate key to the truth.

\section{THE JANUS FACE OF ENLIGHTENMENT}

Toland's idea of a new philosophical hermeneutics was immediately put in a dictionary: one year after publication of Tetradymus the authors of freshly edited Supplément to the $5^{\text {th }}$ edition of Dictionnaire universel françois et latin (known as the Dictionnaire de Trevoux) wrote the following:

ESOTERIC, adj. That which is hidden and not public. The esoteric works of the Ancients cannot be comprehended as they do not provide appropriate clues to do so. These works are opposite to those called exoteric, which were willingly taught in public to anyone. M.[onsieur] Toland said that Plato's works are so full of distincions between what is exoteric and esoteric that he would collect them into a sizable volume. This veiled and hidden doctrine they also called 'Acroatic'. Please, check this term as its explication will not be repeated here ${ }^{19}$.

What was referred there was John Toland's theory from "Clidophorus", accompanied by a nearly verbatim quote. Toland wrote:

All Plato's books are so full of the Exoteric and Esoteric distinction, which is the true key to his works, that out of them alone I cou'd write a sizable volum on this subject. $^{20}$

Two other entries in this Supplément: "Exoterique"21 and "Acroatique",22

\footnotetext{
${ }^{19}$ The original entry: "ÉZOTÉRIQUe, adj. Ce qúi est obscur, caché, \& peu commun. Les ouvrages ézotériques des Anciens ne pouvoient s'entendre, s'ils ne'en donnoient eux-mêmes l'explication. Ces ouvrages étoient opposés à ceux qu'ils nommoient éxotériques, qu'ils expliquoient volontiers publiquement à tout le monde. M. Toland dit que les ouvrages de Platon sont si remplis de la distinction éxotérique, \& ézotérique, qu'il en feroit bien un volume. Ils donnoient aussi à cette doctrine obscure \& cachée le nom d'Acroatique. Voyez ce mot, pour n'en pas répéter isi l'explication." Supplément au Dictionnaire universel françois et latin, vol. 1 (Nancy: Pierre Antoine \& Co., 1752), 1066.

${ }^{20}$ Toland, "Clidophorus," 75.

${ }^{21}$ Supplément, 1058.
} 
were based on "Clidophorus" as well, with the second of them actually translated word by word from Toland's work. ${ }^{23}$

In DGWE, Wouter Hanegraaff pointed out the entry in Dictionnaire de Trevoux as the finale of the evolution of meaning of adjective 'esoteric.' This is true in a very broad sense only: 'esoteric' was generally equated here with teachings that are safely hidden, and juxtaposed to 'exoteric', which was meant to denote all other, "outer" and superficial knowledge. However, this entry actually mentioned Toland by name, which could reasonably lead many readers to accept Toland's grand idea. And that was something completely new, previously unheard of. To accept this grand idea meant to take up Toland's vision of ancient practitioners of a strictest kind of control of knowledge, where the truth is always hidden, and deceit is what is taught in public. This meant putting in general doubt all that had been known until then as key philosophical issues in the West, and after doing so-taking off for a quest for the one and only, esoteric truth. All ancient philosophical stances we knew of, according to Toland's theory, were nothing but a $f a$ çade, a veil, a game of deceit played by 'all philosophers and well-wishers to mankind'. Only esoteric (i.e. hidden, inner) teachings of the ancients were true, universal, and the same in all instances. Toland did not argue about subtleties of meanings of the adjectives themselves. He took them for granted in their most basic version, with which Lucian of Samosata made fun of Aristotelian philosophers. What John Toland argued about was the volume and the importance of the content related to those terms-especially with regard to the doctrine he deemed 'esoteric'. It was the truth: the only, objective, religious and philosophical truth, covered by virtually every single ancient thinker with layers of 'exoteric' teachings - and these were obviously false, contradictory, and multiple. With this came also the statement that all philosophy, all religion, and all ancient wisdom known to humankind, had been deliberately designed that way: the truth had been guarded against possible persecution with a protecting wall of falsehoods.

This idea has been a significant element of what can be described as the general "climate of opinion" of the Enlightenment era. It can be traced with ease throughout this entire period. Toland's Clidophorus, therefore, seems to be the root and the first source of the well-known, tremendous drive of many people of that time towards every single promise of access to some secret, ancient lore. For there were two faces of Enlightenment: the educated, and

\footnotetext{
${ }^{22}$ Ibid., 54.

${ }^{23}$ Toland, "Clidophorus," 74.
} 
the initiatic one. One of common sense, measure, science and reform, the other of mystery, illumination, rituals and secret gatherings, with 'gentlemen of good standing' often entranced by every charlatan's promise of initiation into some ancient, esoteric truth. ${ }^{24}$

Toland's work might also have been an inspiration for another Enlightenment exposition of 'esoteric teachings' as a thing of utmost cultural importance. This one was developed within Masonic movement. Frère (Brother) de la Tierce (his first name remains unknown), the French translator and commentator of James Anderson's Masonic Book of Constitutions (1717), infused the imagination of his contemporaries with the opinionprinted and circulated in many editions of Anderson's book - that everything that is 'esoteric' is actually Masonic. ${ }^{25}$ Like Toland, de la Tierce claimed that "esoteric" meant simply "hidden from the public" but unlike the Irish thinker, the French freemason pointed to the group of people who were supposed to be the only legitimate heirs to all esoteric lore: according to him, they were, and had always been, freemasons.

These two opinions: of Toland (1720), and de la Tierce (1742), combined with the influence of the public edition of Toland's work (1751), and the authority of the famous dictionary (1752), which relied entirely on Toland's "Clidophorus" when it came to 'esoteric' and 'exoteric' doctrines, must have had an impact that is yet to be carefully evaluated. But even a glimpse of Toland's treaty makes it a perfect candidate for one of the main, if not the main culprit responsible for the fact that this huge, "esoteric trait" became part and parcel of the "epoch of lights", thriving especially in the lodges of the $18^{\text {th }}$-century freemasonry.

\footnotetext{
${ }^{24}$ Cf. Auguste Viatte, Les sources occultes du Romantisme: Illuminisme-Théosophie, 17701820, vol. I (Paris: H. Champion, 1927); Antoine FAIVRE, Kirchberger et l'Illuminisme du XVIII siècle (La Haye: Martinus Nijhoff, 1966); IDEM, Mystiques, théosophes et Illuminés au siècle des Lumières (Hildesheim, New York: Georg Olms Verlag, 1976); Joseph de Maistre: Illuminisme et Franc-Maçonnerie: actes du colloque de Chambéry, 4 et 5 mai, 1979, [ed. by a committee from] Universités de Turin et de Savoie, Centre d'études franco-italien (Paris: Société d'Éditions Les Belles Lettres, 1980); Lumières et Illuminisme. Actes du colloque international de Cortona, 3-6 Oct. 1983, ed. Mario Matucci (Pisa: Pacini Editore, 1984); Monika Neugebauer-WöLK, "Illuminaten," in DGWE, 590-97; Jan A.M. SNoek, "Illuminés d'Avignon," in DGWE, 597-600; Andreas B. KILCHER, "Jewish Influences IV: Enlightenment/Romanticism", in DGWE, $642 \mathrm{ff}$.

${ }^{25}$ F[rère] de la Tierce, "Histoire des Francs-Maçons. Premiere partie," in Histoire, Obligations et Statuts de la très vénérable Confraternité des Francs-Maçons tirez de leurs archives et conformes aux traditions les plus anciennes, approuvez de toutes les grandes loges et mis au jour pour l'usage commun des loges répandues sur la surface de la terre (Francofort sur le Meyn: François Varrentrapp, 1742), $38 \mathrm{f}$.
} 
"Clidophorus" has been in circulation since 1720, preaching about the substance, for which not a single nomen proprium had yet been formulated. This grand, and seemingly important, cultural content, this 'esoteric doctrine of the Ancients' surely deserved a name, but Toland did not ventured beyond speaking of it with the use of genus and differentia specifica: it was a 'doctrine,' qualified by him as the 'esoteric one' and 'ancient one.' The scale of it, however, was staggering: it was nothing less than the hidden truth behind all philosophies. "Clidophorus" should be therefore recognized as John Toland's outstanding contribution to the general intellectual climate of the Enlightenment. In the light of his theory the 'Janus face' of this epoch seems to make much more sense.

\section{CONCLUSION}

Toland's work seems likely to be the reason why the Enlightenment, and no earlier or later era, invented the noun 'esotericism' (l'ésotérisme, Esoterismus). The stepping stone for this noun to emerge in 1776 was the heavyweight cultural content bound by Toland to the adjective in 1720 . Toland did not invent the noun. Instead, he imagined a thing of an enormous, cultural importance, and linked it with the adjective 'esoteric', arguing that this was the general, hermeneutic key to the entire philosophical and religious heritage of humanity. This inventive approach to the history of religion and philosophy certainly must have influenced, to some extent, the invention of the esotericism's own nomen proprium. The importance he ascribed to the subject of his theory - 'ancient esoteric doctrine' being supposedly the one and only true religion and philosophy that had been universally known by all the learned Ancients but also universally hidden by them from the publicmight have facilitated the birth of the noun with which we deal today. It certainly represented a new line of thinking. This new importance given to "that which is esoteric" in every part of the world also sheds light on the question why so many esotericists living in the West after Toland's times begun to blend ancient Gnosis with the content of the main currents of western esotericism, why perennialism has become a sort of unofficial creed of regular freemasonry, and why all traces of mystery and secret knowledge outside Western cultural circle, even the most remote and incompatible ones, have become the point of interest of Western esoteric milieus. This, however, is a topic for another, broader study. 


\section{BIBLIOGRAPHY}

\section{SOURCES}

Lucian Of Samosata. "The Sale of the Philosophical Sects.” In IDEm. Lucian of Samosata. Vol. 1. Translated by William Tooke, 215-36, London: Longman, Hurst, Rees, Orme, and Brown, 1820.

Tierce, F.[rère] de la. "Histoire des Francs-Maçons. Première partie." In Histoire, Obligations et Statuts de la très vénérable Confraternité des Francs-Maçons tirez de leurs archives et conformes aux traditions les plus anciennes, approuvez de toutes les grandes loges et mis au jour pour l'usage commun des loges répandues sur la surface de la terre, 1-50. Francofort sur le Meyn: François Varrentrapp, 1742.

Toland, John. "Clidophorus; or of the Exoteric and Esoteric Philosophy, that is, of the External and Internal Doctrine of the antients: the one open and public, accomodated to popular Prejudices and the establish'd Religions; the other private and secret, wherin, to the few capable and discrete, was taught the real TRUTH stript of all disguises." In IDEM. Tetradymus, 63-100. London: Printed and sold by J. Brotherton and W. Meadows in Cornhill, J. Roberts in Warwick-Lane, W. Meres without Temple-Bar, W. Chetwood in CoventGarden, S. Chapman in Pall Mall, and J. Graves in St. James's Street, 1720.

Supplément au Dictionnaire universel françois et latin, contenant la signification et la définition tant des mots de l'une \& de l'autre Langue, avec leurs différens usages, que des termes propres de chaque Etat \& de chaque Profession. La Description de toutes les choses naturelles \& artificielles; leurs figures, leurs espéces, leurs propriétés. L'explication de tout ce que renferment les Sciences \& les Arts, soit Libéraux, soit Méchaniques. Avec des remarques d'érudition et de critique; Le tout tiré des plus excellens Auteurs, des meilleurs Léxicographes, Etymologistes \& Glossaires, qui ont paru jusqu'ici en différentes Langues. Dédié au [Stanisław Leszczyński] Roi de Pologne, Duc de Lorraine \& de Bar. Tome premier. [A-G]. A Nancy: Chez Pierre Antoine, Imprimeur Ordinaire du Roi, \& Compagnie, 1752.

\section{Modern Scholarly Works}

Asprem, Egil. "Reverse-Engineering 'Esotericism': How to Prepare a Complex Cultural Concept for the Cognitive Science of Religion.” Religion 46 (2016), issue 2: 158-85.

Bergé, Christine. "Illuminism." In Dictionary of Gnosis and Western Esotericism, edited by Wouter J. Hanegraaff and Roelof van den Broek, 601-6. Leiden: Brill Academic, 2006.

Broek, Roelof van den, "Gnosticism." In Dictionary of Gnosis and Western Esotericism, edited by Wouter J. Hanegraaff and Roelof van den Broek, 403-32. Leiden: Brill Academic, 2006.

DGWE = Dictionary of Gnosis and Western Esotericism, edited by Wouter J. Hanegraaff and Roelof van den Broek. Leiden: Brill Academic, 2006.

FAIVRE, Antoine. Kirchberger et l'Illuminisme du XVIII siècle. La Haye: Martinus Nijhoff, 1966.

FAIVre, Antoine. Mystiques, théosophes et Illuminés au siècle des Lumières. Hildesheim, New York: Georg Olms Verlag, 1976.

Fouke, Daniel C. Philosophy and Theology in a Burlesque Mode: John Toland and the Way of Paradox. New York: Prometheus Books, 2008.

Hanegraaff, Wouter J."The Birth of Esotericism from the Spirit of Protestantism.” Aries 10 (2010), issue 2: 197-216. 
HANEGRAAFF, Wouter J. "Esotericism." In Dictionary of Gnosis and Western Esotericism, edited by Wouter J. Hanegraaff and Roelof van den Broek, 336-40. Leiden: Brill Academic, 2006.

HanegraAfF, Wouter J. Esotericism and the Academy: Rejected Knowledge in Western Culture. Cambridge: Cambridge University Press, 2012.

JACOB, Margaret C. The Radical Enlightenment: Pantheists, Freemasons and Republicans. New Orleans: Cornerstone Books, 2006.

Joseph de Maistre: Illuminisme et Franc-Maçonnerie: actes du colloque de Chambéry, 4 et 5 mai, 1979, [edited by a committee from] Universités de Turin et de Savoie, Centre d'études franco-italien. Paris: Société d'Éditions Les Belles Lettres, 1980.

Kilcher, Andreas B. "Jewish Influences IV: Enlightenment/Romanticism." In Dictionary of Gnosis and Western Esotericism, edited by Wouter J. Hanegraaff and Roelof van den Broek, 642-44. Leiden: Brill Academic, 2006.

Lumières et Illuminisme. Actes du colloque international de Cortona, 3-6 Oct. 1983, edited by Mario Matucci. Pisa: Pacini Editore, 1984.

Neugebauer-Wölk, Monika. "Illuminaten." Dictionary of Gnosis and Western Esotericism, edited by Wouter J. Hanegraaff, and Roelof van den Broek, 590-97. Leiden: Brill Academic, 2006.

Neugebauer-WöLk, Monika. "Historische Esoterikforschung, oder: Der lange Weg der Esoterik zur Moderne." In Aufklärung und Esoterik: Wege in die Moderne, edited by Renko Geffarth, Markus Meumann, and Monika Neugebauer-Wölk. Berlin, Boston: De Gruyter, 2013.

PAsI, Marco. "The Problems of Rejected Knowledge: Thoughts on Wouter Hanegraaf's Esotericism and the Academy." Religion 43 (2013), issue 2: 201-12.

Snoek, Jan A.M. "Illuminés d'Avignon.” In Dictionary of Gnosis and Western Esotericism, edited by Wouter J. Hanegraaff and Roelof van den Broek, 597-600. Leiden: Brill Academic, 2006.

STĘPIEŃ, Maciej B. Okultyzm: studium ezoteryki zachodniej. Lublin: Academicon, 2015.

StĘPIEŃ, Maciej B. “'Wczesny Faivre' czy 'pełny Hanegraaf’? Dylematy metodologiczne ezoteryki zachodniej." In Tożsamość w ezoterycznych nurtach kultury, edited by Agata Świerzowska and Izabela Trzcińska, 129-44. Kraków: Wydawnictwo LIBRON-Filip Lohner, 2016.

Viatte, Auguste. Les sources occultes du Romantisme: Illuminisme-Théosophie, 1770-1820, Volume 1. Paris: H. Champion, 1927.

\section{THE KEY TO ENLIGHTENMENT: JOHN TOLAND'S “CLIDOPHORUS” AND HIS GRAND THEORY OF THE ESOTERIC AND EXOTERIC DOCTRINES}

\section{S u m m a ry}

"Clidophorus" (from Gr. $\kappa \lambda \varepsilon 1 \delta$ ó (1720) on the history of exoteric and esoteric philosophy. He extensively argued in support of the thesis that the entire philosophical heritage of ancient philosophers of all cultures was but a façade purposely devised by them to protect and hide a deeper, 'esoteric doctrine' from the general public. The author of "Clidophorus," while undermining validity of the then known philosophical heritage, has totally won over the $18^{\text {th }}$-century standard understanding of that which is 
'esoteric' and 'exoteric', especially within the Masonic movement. He also likely influenced the emergence of the related nouns (esotericism, l'esoterisme, Esoterismus). "Clidophorus" is Toland's outstanding contribution to the two-fold profile, clearly visible in the general climate of opinion of the Enlightenment era: one rational, progressive, lay, reformist, and highly educated, the other completely entranced by every charlatan's promise of initiation into supposedly ancient, esoteric truth.

Key words: Western esotericism; John Toland; freemasonry; Enlightenment philosophy, illuminism.

\section{KLUCZ DO OŚWIECENIA: „CLIDOPHORUS” JOHNA TOLANDA I JEGO WIELKA TEORIA DOKTRYN EZOTERYCZNYCH I EGZOTERYCZNYCH}

\section{Streszczenie}

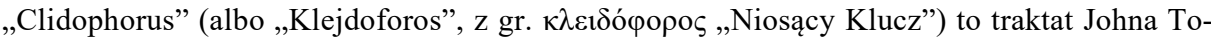
landa dotyczący dziejów filozofii podzielonej na „ezoteryczną” i „egzoteryczną, napisany w $1720 \mathrm{r}$. Jego autor argumentował na rzecz tezy, że całe dziedzictwo starożytnej filozofii, we wszystkich kręgach kulturowych, nie jest niczym innym, jak tylko fasadą, celowo wzniesioną przez starożytnych fillozofów, aby chronić i ukryć ich głębszą, ,ezoteryczną” doktrynę przed wzrokiem gawiedzi. Autor „Klejdoforosa” tym samym podrywał wiarygodność wszystkiego, co stanowiło znane wówczas dziedzictwo filozofii - kwestionował całą filozoficzną tradycję. To jednak, w jaki sposób pojmował on podział na „ezoteryczną” i „egzoteryczną” filozofię, zrobiło w XVIII stuleciu zawrotna karierę, zwłaszcza w lożach wolnomularskich. Jest on więc także, najprawdopodobniej, głównym odpowiedzialnym za zmianę sposobu myślenia, dzięki której w drugiej połowie XVIII wieku spotykamy w źródłach historycznych nieużywane wcześniej neologizmy: rzeczowniki „ezoteryka” i „ezoteryzm” (l'esoterisme, Esoterismus). „Klejdoforos” to zatem również znaczący wkład Tolanda w wykształcenie dwojakiego charakteru epoki oświecenia: $\mathrm{z}$ jednej strony racjonalnego, świeckiego, reformatorskiego i stawiającego na edukację, a z drugiej-idącego ślepo za każdą obietnicą, pochodzącą od każdego szarlatana, jeśli tylko zacznie on mówić o wtajemniczeniu w arkana prawdy ,ezoterycznej” — a więc prawdy ukrytej i zastrzeżonej dla nielicznych.

Słowa kluczowe: ezoteryka zachodnia; John Toland; wolnomularstwo; filozofia oświeceniowa; iluminizm. 